\title{
Precedence of Work Environment Factors Influencing Employee Performance: A RIDIT Approach
}

\author{
V. Ramalakshmi ${ }^{1, *}$, Vivek Kumar Pathak ${ }^{2}$, U.S. Fahis ${ }^{1}$ and Felix Shaji ${ }^{1}$ \\ ${ }^{1}$ Krupanidhi School of Management, Krupanidhi Group of Institutions, Bangalore, \\ India \\ ${ }^{2}$ Accendere Knowledge Management Services, CL Educate Ltd, India
}

\begin{abstract}
Article Type: Conference Proceedings Article

Article Citation: Ramalakshmi V, Vivek Kumar Pathak, Fahis US, Felix Shaji. Precedence of work environment factors influencing employee performance: a RIDIT approach. Indian Journal of Science and Technology. 2020; 13(04), 371-383. D0l: 10.17485/ ijst/2020/v013i04/149814
\end{abstract}

Received date: August 9, 2019

Accepted date: January 2, 2020

*Author for correspondence: $\mathrm{V}$. Ramalakshmi - rama.krupanidhi@ gmail.com 9 Krupanidhi Group of Institutions, Bangalore, India

\begin{abstract}
Objectives: The aim of this study is to analyze the impact of work environment on employee performance and to establish the ranks and prioritize the items related to work environment (WE) in order to maximize employee performance. Methods: Descriptive methodology was used for the study. Association between work environment and employee performance was identified by using correlation analysis. Means of the items of WE were obtained and ranks were provided to the various factors of work environment using RIDIT analysis. Findings/application: The review founds the need to connect work environment with the performance of workers. The managers need to study the rankings provided to the various factors of the work environment and derive the policies or make amendments as and where needed, according to the priority of the factors. This will enhance the overall performance of the employee of the organization as suggested in the study. The uniqueness of this study is, prioritizing the items of work environment with respect to employee performance by using RIDIT analysis. Hence, firms can concentrate and give utmost importance for those items to maximize workers' efficiency and hence organization performance.
\end{abstract}

Keywords: Workplace Environment, Employee Performance, Prioritizing, RIDIT Approach

\section{Introduction}

Employee performance (EP) is determined by various factors. Employees can put their heart and soul for the organization if the work environment (WE) is smooth and comfortable for them. Better work environment inspires the workers and increase their efficiency. Worker's mistake rate, level of novelty and teamwork with other staffs, absence and, duration of stay in the job are influenced by the way they engage with the organization, 
especially with their instantaneous setting. Numerous studies have exposed that if there is no association and mutual understanding between the workers and their immediate managers, then most of the workers leave their organization and their administrators. There is a significant relationship between works, pressure, and health consequences [1]. Studies were done for improving the behavioral work environment and the ways to stop absenteeism of workers due to issues related to well-being [2]. "WE" is all about making circumstances where employees can complete their responsibilities happily [3].

Stability between workers task and demands can be obtained by applying Ergonomics perfectly. Moreover, organizational performance will improve if there is an increase in worker efficiency, worker safety, physical and mental well-being and job satisfaction. Various aspects need to be analyzed about things which have created a situation in which a company requires its workers more than the workers require the company [4]. People operate the surrounding for their survival. Incorrect operations become as a threat and disturb employee performance. Hence workroom requires an atmosphere in which the worker accomplishes his work [5]. An active workroom is a setting in which outcomes can be attained as anticipated by the organization [6-7]. Researchers studied about the psychosocial stressors faced by the employees and analysed about those stressors, the consequences and their significant impact in the work place [8].

Various physical and mental disorders were caused which affect the performance of the workers. Recent researches focus on the factors of "work environment" and top priority is given to "psychosocial factors". The work environment has a significant impact on the psychological and wellbeing of staffs [9]. Clients will feel happy with better work environment design. Hazards and wounds can be reduced or eliminated with better WE and expensive redesigns can be avoided. Experts from the field of Ergonomics and Psychology, create better procedures and products with their knowledge and skills. The present task of any organization is to create an environment which can motivate its employees for improving performance. All the managers in various levels are accountable for this act. They need to brainstorm and innovate new methods to create better work atmosphere in which workers feel comfortable, pleased and satisfied to perform their job. Physical and psychological well-being is affected by the work environment positively and negatively. Expectations about work environment are different and unique in the business world and it is changing in different time frame.

There are lot of changes between the relationship of employer and employee nowadays. In the present economy, employees have plenty of chances and limitless job opportunities. This situation made the condition where employers need their employees rather employees need employer. Hence, the main focus is, to realize about better work environment which is very essential to impress the employees. The output of workers is determined by WE in which they work. WE include all the features which act and react on the heart and soul of an employee. Productivity and performance of employees are optimized by physical, mental, and social environment. The ultimate aim is to create an environment where positive things are maximized and negative things are minimized by considering economic, mechanical, and psychological aspects. Effective WE motivate its workers and help to increase the growth and economy of the firm. Physical, psychological, and social aspects which impact the working conditions are included in the idea of WE. 


\section{Background}

Excellence of work station has an influence on employee's attitude and their performance [10]. Work environment design has an influence on the employee's conduct and is vital in attaining tactical, professional purposes [11]. Enhancement in physical design of office, increases employee productivity [12]. Better results were produced by better work environments. According to American Societies of Interior Designers, employees prefer physical comfort in the office. Organizations which have a better workplace environment, accomplishes the employees' requirements help to improve their productivity [10].

\section{Statement of the Problem}

In many organizations, the workplace atmosphere, its importance and its related problems are pointedly over looked [10]. Less consideration was given to the workroom environment. Employers and workers are not conscious about the effect and changing aspects of workplace environment which causes delay in work accomplishment, hindrance, increase in absenteeism and effect on personal growth, etc [10].

\section{Objectives of the Study}

- To understand the connection between the factors of work environment and workers' performance.

- To rank the items of work environment with respect to their impact on workers' performance.

- To analyze how Physical, Social, and Psychological work environments affect the employees' performance

\section{Literature Survey}

\subsection{Workplace Environment (WE)}

WE play an important role and are one of the vital requirements to complete any job successfully [13]. Numerous researches have tried to explain WE in diverse areas. Factors of WE were studied and researched by many researchers [14-18]. The importance of WE was explained by various scholars [19-21]. Relation between WE and Retention of workers is explained in those studies. Studies on WE were conducted to find the factors which impact employees' decision-making regarding acceptance or rejection of a job [22]. According to many researchers, WE must be taken care very seriously to reduce grievances and absenteeism [13].

Moreover, studies were conducted regarding physical surroundings, office design and their effects on employee performance [18,23-25]. Variations in existence of life, balance of work-life and issues related to well-being are influenced by the factors of WE. Behavioral environment, work place design and connectivity ware analyzed by many researchers to 
obtain extensive knowledge in the domain of WE [25-29]. In many studies, factors of WE were identified and the relationship between WE and EP was proved. Studies regarding collaborative knowledge work environments were conducted by many scholars [24,30-31]. Quality of WE, office personalization, employee wellbeing and effect of new work place were discussed by various researchers [32-35]. Comfort and happiness of the employees are greatly influenced by WE which impacts the success of business also [36]. The present study concentrates on prioritizing the items of WE which improve workers' performance and also identifying the impact of WE on worker performance in terms of wellbeing and satisfaction.

\subsection{Employee Performance (EP)}

Readiness and the sincerity of the employees impact their performance and productivity [37]. Previous studies viewed workers performance in a different manner. Few researchers claimed that attitude and behavior impact employee performance. Attitude and behavior of the workers have significant association with performance [38]. By monitoring employees' behaviors, organizations can improve work performance [39]. Task performance and contextual performance of the workers are led by the behavior of the workers [40]. Companies must have a track on the jobs of the employees to attain objectives of the organization [41]. By doing so, they can watch their employees and help them to progress and maximize their performance that various training and motivation sessions can be helpful for improving performance of the workers [42]. The performance of the workers is very much essential for improving organizations performance. Identifying the factors which affect EP and the role of WE are vital for any institution [43].

\section{Methodology}

The study is descriptive in nature. The population consists of employees of various manufacturing organizations, Bangalore. The sample for the study would be limited to 350 respondents and the list of workers forms the sampling frame. Each worker of the sample constitutes the sampling unit. Stratified sampling method was used for the study.

\section{Analysis and Interpretation}

During data collection, questionnaire was sent to 350 respondents and 273 complete responses were collected. The response rate of the survey is $78 \%$, which is acceptable and suitable for the study. Table 1 shows the mean and standard deviation of the items representing different work environments. Seventy items were taken from Physical, Social, and Psychological work environments out of which only thirty-eight items have mean more than 3.5.

It is observed from Table 2, that the coefficient of relationship between WE and EP is equal to 0.893 . Hence there exists a significant positive relationship between the items of 
TABLE 1. Descriptive statistics

\begin{tabular}{|c|c|c|c|}
\hline & Mean & Std. deviation & $\mathbf{N}$ \\
\hline $\mathrm{EP}$ & 3.5795 & .78414 & 273 \\
\hline WE01 & 3.8205 & .89156 & 273 \\
\hline WE02 & 3.8315 & .83633 & 273 \\
\hline WE03 & 3.8132 & .80776 & 273 \\
\hline WE04 & 3.8901 & .73440 & 273 \\
\hline WE05 & 3.7399 & .92063 & 273 \\
\hline WE06 & 3.8791 & .98334 & 273 \\
\hline WE07 & 3.6886 & .80562 & 273 \\
\hline WE10 & 4.1832 & .73475 & 273 \\
\hline WE11 & 3.7985 & 1.02885 & 273 \\
\hline WE12 & 3.5092 & 1.03652 & 273 \\
\hline WE13 & 3.6557 & 1.07381 & 273 \\
\hline WE16 & 3.5971 & 1.09087 & 273 \\
\hline WE17 & 3.6593 & .96885 & 273 \\
\hline WE20 & 4.3516 & .73825 & 273 \\
\hline WE28 & 3.5971 & .93084 & 273 \\
\hline WE29 & 3.6190 & .87528 & 273 \\
\hline WE30 & 3.7766 & .96895 & 273 \\
\hline WE31 & 3.5897 & 1.03265 & 273 \\
\hline WE33 & 3.6813 & 1.09356 & 273 \\
\hline WE35 & 3.6520 & 1.06747 & 273 \\
\hline WE36 & 3.7179 & .93006 & 273 \\
\hline WE38 & 4.0952 & .78009 & 273 \\
\hline WE39 & 4.1172 & .78649 & 273 \\
\hline WE41 & 3.5531 & .95771 & 273 \\
\hline WE42 & 3.6300 & .96945 & 273 \\
\hline WE44 & 3.8901 & .83733 & 273 \\
\hline WE45 & 3.7216 & .99418 & 273 \\
\hline WE46 & 3.7985 & .82676 & 273 \\
\hline WE50 & 3.5897 & .95496 & 273 \\
\hline WE54 & 3.8278 & .88888 & 273 \\
\hline WE57 & 3.7509 & .96836 & 273 \\
\hline WE58 & 3.6264 & 1.03946 & 273 \\
\hline WE59 & 3.5971 & 1.11421 & 273 \\
\hline WE60 & 4.0842 & .89743 & 273 \\
\hline WE61 & 3.8278 & .90932 & 273 \\
\hline WE64 & 4.0989 & .91219 & 273 \\
\hline WE66 & 3.9890 & .92943 & 273 \\
\hline WE67 & 3.7179 & .97634 & 273 \\
\hline
\end{tabular}

$\mathrm{WE}$ and employee performance. In addition, coefficient of determination is observed from Table 2 and value of $R^{2}$ is equal to 0.798 . Hence fluctuations in the performance of workers can be elucidated by the fluctuations in work environment items.

Based on the regression analysis, it was found that the explainable value was 0.798 . This model had used 38 independent items i.e. WE01, WE02, WE03, WE04, WE05, WE06, WE07, WE10, WE11, WE12, WE13, WE16, WE17, WE20, WE28, WE29, WE30, WE31, WE33, WE35, WE36, WE38, WE39, ,WE41, WE42, WE44, WE45, WE46, WE50, WE54, WE57, WE58, WE59, WE60, WE61, WE64, WE66, and WE67 which were representing work environment items. 
Precedence of Work Environment Factors Influencing Employee Performance: A RIDIT Approach

TABLE 2. Model summary

\begin{tabular}{|c|c|c|c|c|c|c|c|c|c|c|}
\hline \multirow[b]{2}{*}{ Model } & \multirow[b]{2}{*}{$R$} & \multirow[b]{2}{*}{$\begin{array}{l}R \\
\text { square }\end{array}$} & \multirow[b]{2}{*}{$\begin{array}{l}\text { Adjusted } \\
R \text { square }\end{array}$} & \multirow{2}{*}{$\begin{array}{l}\text { Std. error } \\
\text { of the } \\
\text { estimate }\end{array}$} & \multicolumn{5}{|c|}{ Change statistics } & \multirow[b]{2}{*}{$\begin{array}{l}\text { Durbin- } \\
\text { Watson }\end{array}$} \\
\hline & & & & & $\begin{array}{l}R \text { square } \\
\text { change }\end{array}$ & $\begin{array}{l}F \\
\text { change }\end{array}$ & df1 & df2 & $\begin{array}{l}\text { Sig. } F \\
\text { change }\end{array}$ & \\
\hline 1 & $.893^{\mathrm{a}}$ & .798 & .765 & .38018 & .798 & 24.293 & 38 & 234 & .000 & 2.076 \\
\hline
\end{tabular}

aPredictors: (constant), WE67, WE05, WE13, WE16, WE03, WE20, WE11, WE54, WE33, WE12, WE04, WE17, WE64, WE06, WE46, WE28, WE07, WE29, WE50, WE44, WE39, WE41, WE02, WE35, WE38, WE10, WE42, WE66, WE30, WE60, WE31, WE01, WE59, WE36, WE45, WE58, WE61, and WE57.

bDependent variable: EP.

TABLE 3. ANOVA

\begin{tabular}{llccccc}
\hline Model & & $\begin{array}{c}\text { Sum of } \\
\text { squares }\end{array}$ & df & $\begin{array}{c}\text { Mean } \\
\text { square }\end{array}$ & $\boldsymbol{F}$ & Sig. \\
\hline 1 & Regression & 133.424 & 38 & 3.511 & 24.293 & $.000^{\mathrm{b}}$ \\
& Residual & 33.821 & 234 & .145 & & \\
& Total & 167.245 & 272 & & & \\
\hline
\end{tabular}

aDependent variable: employee performance.

bPredictors: (constant), WE67, WE05, WE13, WE16, WE03, WE20, WE11, WE54, WE33, WE12, WE04, WE17, WE64, WE06, WE46, WE28, WE07, WE29, WE50, WE44, WE39, WE41, WE02, WE35, WE38, WE10, WE42, WE66, WE30, WE60, WE31, WE01, WE59, WE36, WE45, WE58, WE61, and WE57.

From the previous Table 3, it was found that only 13 items were having significant relationship with the dependent variable, "employee performance". The items found significant were WE01, WE02, WE05, WE06, WE16, WE29, WE35, WE36, WE42, WE44, WE64, and WE66.

Only these 13 items were considered for further analysis in the present study.

TABLE 4. Coefficients ${ }^{\mathrm{a}}$

\begin{tabular}{|c|c|c|c|c|c|c|}
\hline \multirow{2}{*}{\multicolumn{2}{|c|}{$\begin{array}{l}\text { Model } \\
\text { B }\end{array}$}} & \multicolumn{2}{|c|}{ Unstandardized coefficients } & \multirow[t]{2}{*}{$\begin{array}{l}\text { Standardized } \\
\text { coefficients }\end{array}$} & \multirow[b]{2}{*}{$\mathbf{t}$} & \multirow[b]{2}{*}{ Sig. } \\
\hline & & Std. error & Beta & & & \\
\hline \multirow[t]{10}{*}{1} & (Constant) & .549 & .220 & & 2.491 & .013 \\
\hline & WE01 & .095 & .049 & .108 & 1.942 & .053 \\
\hline & WE02 & -.098 & .049 & -.104 & -1.995 & .047 \\
\hline & WE03 & .017 & .041 & .017 & .410 & .682 \\
\hline & WE04 & .047 & .047 & .044 & 1.010 & .313 \\
\hline & WE05 & -.057 & .032 & -.067 & -1.803 & .073 \\
\hline & WE06 & .086 & .035 & .108 & 2.457 & .015 \\
\hline & WE07 & -.028 & .046 & -.028 & -.603 & .547 \\
\hline & WE10 & .022 & .051 & .020 & .425 & .671 \\
\hline & WE11 & -.032 & .032 & -.042 & -.984 & .326 \\
\hline
\end{tabular}




\begin{tabular}{|c|c|c|c|c|c|}
\hline WE12 & .014 & .031 & .018 & .454 & .650 \\
\hline WE13 & .034 & .028 & .047 & 1.205 & .230 \\
\hline WE16 & -.070 & .033 & -.097 & -2.134 & .034 \\
\hline WE17 & .005 & .035 & .006 & .145 & .885 \\
\hline WE20 & -.029 & .043 & -.028 & -.681 & .497 \\
\hline WE28 & -.039 & .037 & -.047 & -1.074 & .284 \\
\hline WE29 & .103 & .046 & .115 & 2.216 & .028 \\
\hline WE30 & -.035 & .042 & -.044 & -.843 & .400 \\
\hline WE31 & -.011 & .040 & -.014 & -.261 & .794 \\
\hline WE33 & .010 & .033 & .015 & .315 & .753 \\
\hline WE35 & .060 & .035 & .082 & 1.706 & .089 \\
\hline WE36 & .096 & .046 & .114 & 2.070 & .040 \\
\hline WE38 & -.058 & .049 & -.058 & -1.196 & .233 \\
\hline WE39 & .011 & .047 & .011 & .231 & .817 \\
\hline WE41 & -.019 & .041 & -.023 & -.459 & .647 \\
\hline WE42 & -.110 & .040 & -.136 & -2.783 & .006 \\
\hline WE44 & .095 & .041 & .101 & 2.293 & .023 \\
\hline WE45 & .073 & .045 & .093 & 1.628 & .105 \\
\hline WE46 & .043 & .045 & .045 & .958 & .339 \\
\hline WE50 & .048 & .036 & .058 & 1.347 & .179 \\
\hline WE54 & -.022 & .038 & -.025 & -.584 & .560 \\
\hline WE57 & .093 & .065 & .115 & 1.425 & .156 \\
\hline WE58 & .077 & .058 & .102 & 1.333 & .184 \\
\hline WE59 & .024 & .051 & .035 & .479 & .632 \\
\hline WE60 & .011 & .053 & .013 & .217 & .829 \\
\hline WE61 & .056 & .067 & .065 & .832 & .406 \\
\hline WE64 & -.089 & .038 & -.103 & -2.335 & .020 \\
\hline WE66 & .095 & .043 & .112 & 2.217 & .028 \\
\hline WE67 & .296 & .056 & .369 & 5.270 & .000 \\
\hline
\end{tabular}

${ }^{a}$ Dependent variable: EP.

\subsection{RIDIT Analysis for Work Environment Items}

RIDIT analysis was familiarized by I. Bross, and has been used in various functional areas of business. Postulation about the distribution is not compulsory since it is distribution free [42-43]. RIDIT score can be derived with the help of mathematical methods. RIDIT analysis converts ordinal data to a probability scale. Prominently, RIDIT analysis is firmly connected to the Wilcoxon rank sum test. Mean RIDIT and Wilcoxon test statistic are directly connected.

Hypothesis that there is no significant difference between mean RIDITS across all groups using a $\chi^{2}$ statistic can be tested [44]. Similar test between any group and the 
Precedence of Work Environment Factors Influencing Employee Performance: A RIDIT Approach

TABLE 5. RIDIT values for the reference dataset

\begin{tabular}{lrrrrrr}
\hline & $\mathbf{1}$ & $\mathbf{2}$ & $\mathbf{3}$ & $\mathbf{4}$ & $\mathbf{5}$ & \\
\hline WE01 & 6 & 15 & 56 & 141 & 55 & 273 \\
WE02 & 3 & 17 & 53 & 150 & 50 & 273 \\
WE05 & 6 & 20 & 64 & 132 & 51 & 273 \\
WE06 & 4 & 26 & 48 & 116 & 79 & 273 \\
WE16 & 14 & 26 & 77 & 95 & 61 & 273 \\
WE29 & 1 & 29 & 83 & 120 & 40 & 273 \\
WE35 & 10 & 37 & 48 & 121 & 57 & 273 \\
WE36 & 4 & 26 & 65 & 126 & 52 & 273 \\
WE42 & 9 & 23 & 74 & 121 & 46 & 273 \\
WE44 & 3 & 14 & 52 & 145 & 59 & 273 \\
WE64 & 9 & 5 & 32 & 131 & 96 & 273 \\
WE66 & 8 & 9 & 44 & 129 & 83 & 273 \\
WE67 & 11 & 13 & 74 & 119 & 56 & 273 \\
Freq & 88 & 260 & 770 & 1646 & 785 & 3549 \\
1/2 freq & 44 & 130 & 385 & 823 & 392.5 & \\
Ri & 44 & 218 & 733 & 1941 & 3156.5 & \\
Ri & 0.012398 & 0.061426 & 0.206537 & 0.546915 & 0.889405 & \\
\hline
\end{tabular}

reference group was defined by them. Work environment data and employee performance were chosen as reference data set. The frequencies of the responses are exposed in Table 4 . The last row of reference dataset represents the RIDIT values of the reference data set for each item in the following Table 5.

RIDIT values are derived by summing the weights. Priority rankings connected with the RIDIT scores are provided in the following table.

TABLE 6. Calculation of the RIDIT values for the comparison datasets and prioritization

\begin{tabular}{cccccccccc}
\hline & $\mathbf{1}$ & $\mathbf{2}$ & $\mathbf{3}$ & $\mathbf{4}$ & $\mathbf{5}$ & $\mathbf{\rho i}$ & $\begin{array}{c}\text { Lower } \\
\text { bound }\end{array}$ & $\begin{array}{c}\text { Upper } \\
\text { bound }\end{array}$ & $\begin{array}{c}\text { Priority } \\
\text { ranking }\end{array}$ \\
\hline WE01 & 0.0003 & 0.0034 & 0.0424 & 0.2825 & 0.1792 & 0.5077 & 0.4323 & 0.5830 & 5 \\
WE02 & 0.0001 & 0.0038 & 0.0401 & 0.3005 & 0.1629 & 0.5075 & 0.4293 & 0.5856 & 6 \\
WE05 & 0.0003 & 0.0045 & 0.0484 & 0.2644 & 0.1662 & 0.4838 & 0.4142 & 0.5534 & 7 \\
WE06 & 0.0002 & 0.0059 & 0.0363 & 0.2324 & 0.2574 & 0.5321 & 0.4551 & 0.6091 & 3 \\
WE16 & 0.0006 & 0.0059 & 0.0583 & 0.1903 & 0.1987 & 0.4538 & 0.3949 & 0.5127 & 12 \\
WE29 & 0.0000 & 0.0065 & 0.0628 & 0.2404 & 0.1303 & 0.4401 & 0.3796 & 0.5005 & 13 \\
WE35 & 0.0005 & 0.0083 & 0.0363 & 0.2424 & 0.1857 & 0.4732 & 0.4057 & 0.5407 & 10 \\
WE36 & 0.0002 & 0.0059 & 0.0492 & 0.2524 & 0.1694 & 0.4770 & 0.4099 & 0.5442 & 9 \\
WE42 & 0.0004 & 0.0052 & 0.0560 & 0.2424 & 0.1499 & 0.4538 & 0.3910 & 0.5166 & 11 \\
WE44 & 0.0001 & 0.0032 & 0.0393 & 0.2905 & 0.1922 & 0.5253 & 0.4467 & 0.6039 & 4 \\
WE64 & 0.0004 & 0.0011 & 0.0242 & 0.2624 & 0.3128 & 0.6009 & 0.5078 & 0.6941 & 1 \\
WE66 & 0.0004 & 0.0020 & 0.0333 & 0.2584 & 0.2704 & 0.5645 & 0.4805 & 0.6485 & 2 \\
WE67 & 0.0005 & 0.0029 & 0.0560 & 0.2384 & 0.1824 & 0.4802 & 0.4147 & 0.5458 & 8 \\
\hline
\end{tabular}

Taking the first row in Table 6 which has the variable OB01, the value of 0.0003 is derived from Table 5 by multiplying the frequency of 6 (from the row marked WE01 in Table 5) by the reference group RIDIT values of 0.012398 (found in the bottom row of Table 5) and 
then dividing by the value of $\mathrm{N}$ (273) (from the last column of Table 5). RIDIT scores were obtained by adding the weights from the five columns. Statistically, the average RIDIT value will be 0.5 . Those items with comparatively more response of 5 and 4 will tend to have a RIDIT value of larger than 0.5. Those items with relatively more responses of 2 and 1 will have a RIDIT value of less than 0.5 . Subsequently, the higher the RIDIT value is the higher priority the sample places on the item will be. We allocate priority rankings to the items with the highest priority going to the maximum RIDIT value. The Kruskal-Wallis ' $\mathrm{W}$ ' was calculated to be 84.825 . Because the value of $\mathrm{W}$ (84.825) is significantly bigger than $\chi^{2}(13-1)=22.362$, it can be understood that the opinions about the scale items among the respondents vary statistically. It is nonparametric and based on ranks. It is used to test whether there are significant differences among two or more groups of the items of work environment. This test does not demand that the data should be normal. Perhaps the ranks of the data values ware used for analysis.

From the RIDIT ranking analysis (Table 6), it was identified that out of all the work environment items, the item which states, "Cooperation, support, and empowerment exist in the organization" was given utmost priority by the respondents followed by the item which states, "Compassion, respect and understanding exist in the organization", "My organization is training and development focused", "There exists strong leadership from the top management" whereas the least priority was assigned to the item which states, "In the organization conflicts resolved in a fair way". Using RIDIT analysis, the overall ranking of the items of work environment was shown in Table 6.

\section{Discussion}

There exists a significant positive relationship between the items of work environment and employee performance. In addition, the study established the priority ranks of the items of work environment in order to maximize employee performance. According to the results, companies need to concentrate more on creating a work environment where cooperation, support, compassion, respect, and understanding exist always in the organization in order to improve the performance of the employees. Moreover, an organization needs to focus on training and development to improve employee performance. Employees need to sense challenged and to be given assignments that motivate, test, and stretch their capabilities. Better selection and connection of team members also play a vital role to improve employee performance.

The administrative team of the organization needs to offer an environment in which morality and honesty are valued. State of the art technology needs to be used and the employees need to be trained to expertise in various fields. Staffs need to feel accepted and treated with courtesy, listened to, and invited to express their thoughts and feelings by the top management. Organizations need to have a fun and productive atmosphere so that employees feel happy to work there. Workers need to have optimistic working relationships among them. Conflicts need to be resolved in a fair-minded way in the organization. In many studies, factors of WE were identified and the relationship between WE and EP was proved. But the uniqueness of this study is, prioritizing the items of WE with respect to 
EP by using RIDIT analysis. Hence, firms can concentrate and give utmost importance for those items to improve the efficiency of staffs and thus organization performance.

\section{Limitations and Future Scope of the Study}

This study was aimed to assess the impact of work environment on employee performance in manufacturing industries of Bangalore city in India. In spite of valuable outcomes of the present study, this study possesses few limitations. One major limitation of the study is that the findings cannot be generalised as the sample represented in the study belongs to a specific geography and demography. Future studies are suggested to extend the geographical area and increase the sample size for more in-depth conclusions. Second limitation is that of the identified factors as the present study may have not accessed few crucial factors due to the infrastructural restrictions. Future studies need to explore more extensive literature reviews to get other significant factors of work environment that may have a significant influence on employee performance. Another limitation lies in the sample domain selected for the study. Future studies may try the explored factor and its influence in different industry verticals. Last but not the least; the time always has its constraints and limitations in academic researches. That was true for the present study also.

\section{Managerial Implications}

The findings of the present study, in its present state, do have the ability to influence the HR decision making for the manufacturing industries similar to the nature of the sample represented. The managers need to study the rankings provided to the various factors of work environment and derive the policies or make amendments as and where needed according to the priority of the factors. This will enhance the overall performance of the employee of the organization as suggested in the study. Priority rakings should be used by the managers to decide their course of actions as to which one to focus more and which one later. This will also improve the organizational efficiency as a whole.

\section{Acknowledgement}

The authors express their sincere gratitude to The Management, Krupanidhi Group of Institutions for supporting the work through Krupanidhi Research Incubator Centre (K-RIC) program and Accendere: CL Educate Ltd.

\section{References}

1. Shirom A. The effects of work stress on health. The handbook of work and health psychology. 2003; 2, 63-82. https://doi.org/10.1002/0470013400.ch4 
2. Van Bogaert P, Meulemans H, Clarke S, Vermeyen K, Van de Heyning P. Hospital nurse practice environment, burnout, job outcomes and quality of care: test of a structural equation model. Journal of Advanced Nursing. 2009; 65(10), 2175-2185. https://doi. org/10.1111/j.1365-2648.2009.05082.x

3. Gitonga L, Gachunga H. Influence of work environment on organizational performance in government ministries in Kenya. Strategic Journal of Business \& Change Management. 2015; 2(2), 1-29. http://www.strategicjournals.com/index.php/journal/article/view/157/167

4. Smith DG. Work environment more important to employees. Retrieved November. 2011, 25. https://www.coursehero.com/file/pjvlqen/Smith-DG-2011-Work-environment-more-importantto-employees-Retrieved-November/

5. Ajala EM. The influence of workplace environment on workers' welfare, performance and productivity. In: The African Symposium. 2012. https://www.semanticscholar.org/paper/THEINFLUENCE-OF-WORKPLACE-ENVIRONMENT-ON-WORKERS'-Ajala/24e57a6b52d6e8f 5c61f7349d0d7a14d7d6f4018

6. Mike A. Visual workplace: How you see performance in the planet and in the office. International Journal of Financial Trade. 2010; 11(3), 250-260. https://www.ijser.org/researchpaper/WorkingEnvironment-and-Productivity.pdf

7. Shikdar A, Al-Araimi S, Omurtag B. Development of a software package for ergonomic assessment of manufacturing industry. Computers \& Industrial Engineering. 2002; 43(3), 485493. https://doi.org/10.1016/S0360-8352(02)00121-3

8. Kristensen TS, Hannerz H, Høgh A, Borg V. The Copenhagen Psychosocial Questionnaire-a tool for the assessment and improvement of the psychosocial work environment. Scandinavian Journal of Work, Environment \& Health. 2005; 438-449. DOI: 10.5271/sjweh.948

9. Gitonga L, Gachunga H. Influence of work environment on organizational performance in government ministries in Kenya. Strategic Journal of Business \& Change Management. 2015; 2(2).

10. Hameed A, Amjad S. Impact of office design on employee's productivity: a case study of banking organizations of Abbottabad, Pakistan. 2009. https://www.researchgate.net/ publication/242109623_Impact_of_Office_Design_on_Employees'_Productivity_A_Case_ Study_of_Banking_Organizations_of_Abbottabad_Pakistan

11. Mandhanya Y. A Study of impact of working environment on retention of employees (with special reference to automobile sector. Global Management Review. 2015; 9(4), 116-128. https:// web.b.ebscohost.com/abstract? direct $=$ true $\&$ profile $=$ ehost $\&$ scope $=$ site $\&$ authtype $=$ crawler\&jrnl=09739947\&AN=113664247\&h=JvsojX\%2bJ7nDeJzpxZQPH1v2YsXOaC5 rlnw67E 82 R KD 2 a M KPOUXs 7 fNZBNERW s 3 J M 5 fy GT Ks\% 2 bjKIukcFYPO jPg\%3d\%3d\&crl=f\&resultNs=AdminWebAuth\&resultLocal=ErrCrlNotAuth\&crlhashurl= login.aspx\%3fdirect\%3dtrue\%26profile\%3dehost\%26scope\%3dsite\%26authtype\%3dcrawler\% 26jrnl\%3d09739947\%26AN\%3d113664247

12. Naharuddin N, Sadegi M. Factors of workplace environment that affect employees' performance: a case study of Miyazu Malaysia. International Journal of Independent Research and Studies. 2013; 2(2), 66-78. https://papers.ssrn.com/sol3/papers.cfm?abstract_id=2290214

13. Leblebici D. Impact of workplace quality on employee's productivity: case study of a bank in Turkey. Journal of Business, Economics. 2012; 1(1), 38-49. https://www.semanticscholar. org/paper/Impact-of-Workplace-Quality-on-Employee\%E2\%80\%99s-Study-of-Leblebici/ f4e54efb443c243411e6c81986938ce02c5f93a5

14. Becker FD, Steele F. Workplace by design: mapping the high-performance works cape. JosseyBass. 1995; 228. https://cmc.marmot.org/Record/.b12243905 
15. Chaubey A, Sahoo CK, Khatri N. Relationship of transformational leadership with employee creativity and organizational innovation: a study of mediating and moderating influences. Journal of Strategy and Management. 2019; 12(1), 61-82. https://doi.org/10.1108/JSMA-07-2018-0075

16. Sims W. Team space: planning and managing environments to support team work. International Journal of Facilities Management. 2000; 1(1), 21-33. https://www.coursehero.com/file/p5fn5oh/ Make-sure-the-values-and-ethics-of-the-company-are-of-those-employees-can-take/

17. Bitner MJ. Servicescapes: the impact of physical surroundings on customers and employees. Journal of Marketing. 1992; 56(2), 57-71. https://www.ida.liu.se/ steho87/und/ htdd01/9208310667.pdf

18. Brennan A, Chugh JS, Kline T. Traditional versus open office design: a longitudinal field study. Environment and Behavior. 2002; 34(3), 279-299. https://doi.org/10.1177 $\% 2 \mathrm{~F} 0013916502034003001$

19. Lans T, Biemans H, Verstegen J, Mulder M. The influence of the work environment on entrepreneurial learning of small-business owners. Management Learning. 2008; 39(5), 597613. https://doi.org/10.1177\%2F1350507608098117

20. Ross LE, Boles JS. Exploring the influence of workplace relationships on work-related attitudes and behaviors in the hospitality work environment. International Journal of Hospitality Management. 1994; 13(2), 155-171. https://doi.org/10.1016/0278-4319(94)90036-1

21. Göransson S, Näswall K, Sverke M. Work-related health attributions: their impact on work attitudes. International Journal of Workplace Health Management. 2009; 2(1), 6-21. https://doi. org/10.1108/17538350910945974

22. Earle HA. Building a workplace of choice: using the work environment to attract and retain top talent. Journal of Facilities Management. 2003; 2(3), 244-257. DOI: 10.1108/14725960410808230

23. Becker F, Sims W. Offices that work. International workplace studies program, Cornell University: New York. 2001; 129-149. https://cpb-us-e1.wpmucdn.com/blogs.cornell.edu/ dist/a/3723/files/2013/09/offices-that-work-2hhjfmx.pdf

24. Haynes B, Price I. Quantifying the complex adaptive workplace. Facilities. 2004; 22(1/2), 8-18. DOI: $10.1108 / 02632770410517906$

25. Duffy F. The changing workplace. Phaidon Press. 1992; 251. https://books.google.co.in/books/ about/The_Changing_Workplace.html?id=PrlPAAAAMAAJ\&redir_esc=y

26. Go with the flow. https://en.wikipedia.org/wiki/Go_with_the_Flow. Date accessed: 30/12/2019.

27. DeMarco T, Lister T. People ware: productive projects and teams. Dorset House Publishing Co. Inc.: New York, NY, USA. 1987; 188. https://dl.acm.org/doi/book/10.5555/31844

28. Price IF, Matzdorf F, Smith L, Agahi H. The impact of facilities on student choice of university. Facilities. 2003; 21(10), 212-22. DOI: 10.1108/02632770410517933

29. Fleming D. Facilities management: a behavioural approach. Facilities. 2004; 22(1/2), 35-43.

30. Heerwagen JH, Kampschroer K, Powell KM, Loftness V. Collaborative knowledge work environments. Building Research \& Information. 2004; 32(6), 510-528. https://doi.org/10.1080/ 09613210412331313025

31. Hurst DK. Crisis and renewal: meeting the challenge of organizational change. Harvard Business School Press. 1995; 229. https://searchworks.stanford.edu/view/10056991

32. WardV,Holtham C. Theroleofprivateand publicspacesin knowledgemanagement. Victoria.2000; 20(7250), 1202. https://www.researchgate.net/publication/228390453_The_role_of_private_ and_public_spaces_in_knowledge_management

33. Wells MM. Office clutter or meaningful personal displays: the role of office personalization in employee and organizational well-being. Journal of environmental psychology. 2000; 20(3), 239-55. https://doi.org/10.1006/jevp.1999.0166 
34. Turner G, Myerson J. New workspace, new culture: office design as a catalyst for change. Gower Publishing, Ltd. 1998; 144. https://doi.org/10.4324/9781315247977

35. Stokols D, Clitheroe C, Zmuidzinas M. Qualities of work environments that promote perceived support for creativity. Creativity Research Journal. 2002; 14(2), 137-147. https://doi.org/10.1207/ S15326934CRJ1402_1

36. Morgeson FP, Garza AS, Campion MA. Work design. Handbook of psychology, 2nd edn. 2012; 12. https://doi.org/10.1002/9781118133880.hop212020

37. Lankeshwara P. A study on the impact of workplace environment on employee's performance: with reference to the Brandix Intimate Apparel-Awissawella. International Journal of Multidisciplinary Studies. 2016, 3(1), 1-11. http://journals.sjp.ac.lk/index.php/ijms/article/ view/2830/1872

38. Nguyen PD, Dang CX, Nguyen LD. Would better earning, work environment, and promotion opportunities increase employee performance? An investigation in state and other sectors in Vietnam. Public Organization Review. 2015; 15(4), 565-579. https://link.springer.com/ article/10.1007/s11115-014-0289-4

39. Kacmar KM, Collins BJ, Harris KJ, Judge TA. Core self-evaluations and job performance: the role of the perceived work environment. Journal of Applied Psychology. 2009; 94(6), 1572. https://psycnet.apa.org/doi/10.1037/a0017498

40. Stup R. Control the factors that influence employee success. Managing the Hispanic workforce Conference. Cornell University and Pennsylvania State University. 2003. http://freedownloadmsdm.blogspot.com/2010/05/control-factors-that-influence-employee.html

41. Chandrasekar K. Workplace environment and its impact on organisational performance in public sector organisations. International Journal of Enterprise Computing and Business Systems. 2011; 1(1), 1-9. http://www.ijecbs.com/January2011/N4Jan2011.pdf

42. Hair Jr JF, Sarstedt M, Hopkins L, Kuppelwieser G. Partial least squares structural equation modeling (PLS-SEM): an emerging tool in business research. European Business Review. 2014; 26(2), 106-121. https://doi.org/10.1108/EBR-10-2013-0128

43. Jansen ME. Ridit analysis, a review. Statistica Neerlandica. 1984; 38(3), 141-158. https://doi. org/10.1111/j.1467-9574.1984.tb01106.x

44. Fleiss JL, Levin B, Paik MC. Statistical methods for rates and proportions. John Wiley \& Sons. 2013. https://www.scirp.org/(S(czeh2tfqyw2orz553k1w0r45))/reference/ReferencesPapers. aspx?ReferenceID=2119421 